\title{
Plant parasitic nematodes associated with six subtropical crops in New Zealand
}

\author{
K. W. L. KNIGHT \\ National Plant Pest Reference Laboratory \\ Ministry of Agriculture and Forestry \\ P. O. Box 24, Lincoln \\ New Zealand \\ email:knightk@maf.govt.nz
}

\begin{abstract}
The plant parasitic nematode fauna was examined from the soil and roots of six subtropical crops. Six nematode species not previously reported in New Zealand were discovered: Criconema annuliferum (de Man, 1921) Micoletzky, 1925; Crossonema civellae (Steiner, 1949) Mehta \& Raski, 1971; Helicotylenchus paraplatyurus Siddiqi, 1972; Paratylenchus elachistus Steiner, 1949; Scutellonema brachyurus (Steiner, 1949) Andrassy, 1958; and Zygotylenchus guevarai (Tobar Jimenez, 1963) Braun \& Loof, 1966. Six pest:host relationships, not previously recorded in New Zealand, are proposed: Pratylenchus crenatus on the hosts Passiflora edulis and Cyphomandra betaceae, Pratylenchus penetrans and Zygotylenchus guevarai on $P$. edulis, Tylenchulus semipenetrans on Diospyros kaki, and Meloidogyne hapla on Persea americana.
\end{abstract}

Keywords nematode; avocado; kiwifruit; persimmon; feijoa; passionfruit; tamarillo

\section{INTRODUCTION}

Between September 1998 and June 1999 a national survey of plant pests and diseases was conducted on six subtropical fruit crops in New Zealand: avocado (Persea americana Mill.), feijoa (Feijoa sellowiana O. Berg.), kiwifruit (Actinidia deliciosa (A. Chev.)

H01016

Received 19 April 2001; accepted 29 August 2001
C.F. Liang et A.R. Fergusson), passionfruit (Passiflora edulis Sims.), persimmon (Diospyros kaki L.f.), and tamarillo (Cyphomandra betacea (Cav.) Sendtner). The objective of this survey was to provide an accurate record of the occurrence and distribution of plant pests and diseases associated with these crops including: those pests and diseases already known to occur in New Zealand in association with these hosts; new associations (pests and diseases known to occur in the country but not known in association with these hosts including new pest:host relationships); and plant pests and diseases not previously recorded in New Zealand. This paper reports the plant parasitic nematode component of that survey.

Before this survey, little work had been done on plant parasitic nematodes in subtropical crops in New Zealand. The root knot nematode, Meloidogyne incognita (Kofoid \& White, 1919) Chitwood, 1949 , had been implicated in reducing the productivity of tamarillo (Cooper \& Grandison 1987) and Meloidogyne hapla Chitwood, 1949 had been acknowledged as a common parasite of kiwifruit (Sale 1985). Sale, however, reported little restriction of vigour or loss of crop production as a result of $M$. hapla parasitism on established kiwifruit vines unless they are suffering other stresses. During a 1 year study of kiwifruit, Watson et al. (1992) found $M$. hapla to be the only plant parasitic nematode consistently associated with kiwifruit roots.

\section{MATERIALS AND METHODS}

\section{Sites}

The survey covered the geographical range of the crops within the country, including domestic sites and all commercial production areas, in approximately the ratio of occurrence of these crops in these areas. For the purposes of both selecting the sites and tracking known and new distributions the system of Crosby et al. (1976) districts was used. In this system New Zealand is divided into 29 
approximately equally sized areas designated by two-letter codes. The districts where subtropical crops were sufficiently represented for survey were: AK (Auckland), BP (Bay of Plenty), CL (Coromandel), GB (Gisborne), HB (Hawke's Bay), MB (Marlborough), ND (Northland), NN (Nelson), TK (Taranaki), WI (Wanganui), WN (Wellington), and WO (Waikato).

\section{Sampling}

Samples consisted of a total of 2 litres of soil taken from at least 10 locations within a commercial crop, with a bias to areas in the crop showing reduced vigour, nutrient deficiency, or poor growth. In domestic sites, with fewer host plants, 0.5 litre of soil was collected. Samples were taken to a depth of $20 \mathrm{~cm}$ in the drip zone of the host. Roots were collected at all sites where they could be differentiated from the roots of neighbouring species. Areas, where the roots of weeds or other species may have been present, were avoided wherever possible. Where this was not possible the laboratory was alerted to the possibility that any nematodes present might be associated with nontarget hosts.

\section{Extraction}

The soil was thoroughly mixed. Nematodes were extracted from a $250-300 \mathrm{ml}$ subsample using a modified Whitehead tray (Whitehead \& Hemming 1965 ) for $48-72 \mathrm{~h}$. The extract was then condensed

Table 1 Plant parasitic nematodes associated with avocado (Persea americana) in New Zealand, $1998-99$.

\begin{tabular}{|c|c|c|c|c|c|c|c|c|}
\hline \multirow[b]{4}{*}{ Nematode } & \multicolumn{8}{|c|}{ Number of sites surveyed $($ total $=95)$} \\
\hline & 75 & 3 & 2 & 1 & 10 & 1 & 2 & 1 \\
\hline & \multicolumn{8}{|c|}{ Crosby et al. (1976) district } \\
\hline & ND & $\mathrm{AK}$ & WO & $\mathrm{CL}$ & $\mathrm{BP}$ & GB & TK & NN \\
\hline \multicolumn{9}{|l|}{ Triplonchida } \\
\hline Paratrichodorus minor & 13 & & & & & & 2 & \\
\hline P. porosus & 8 & & & & 3 & & & \\
\hline Paratrichodorus sp. & 1 & & & & & & & \\
\hline \multicolumn{9}{|l|}{ Dorylaimida } \\
\hline Xiphinema diversicaudatum & 1 & & & & & & & \\
\hline$X$. americanum & 7 & & & & 1 & & & \\
\hline Xiphinema sp. & 1 & & & & & & & \\
\hline Longidorus elongatus & & & & & & & 1 & \\
\hline \multicolumn{9}{|l|}{ Tylenchida } \\
\hline Meloidogyne hapla ${ }^{\dagger}$ & 11 & & & & & & & \\
\hline M. trifoliophila & 1 & & & & & & & \\
\hline Meloidogyne sp. & 2 & & & & & & & \\
\hline Heterodera sp. & 1 & & & & & & & \\
\hline Pratylenchus crenatus & $3+$ & & & & & & & \\
\hline Pratylenchus sp. & 1 & & & & 1 & & & \\
\hline Paratylenchus elachistus & 9 & & & $1^{\ddagger}$ & 1 & & & \\
\hline P. nanus & $2^{+}$ & & & & & & & \\
\hline P. projectus & & & & $1+$ & & & & \\
\hline Tylenchulus semipenetrans & & & & & & 1 & & \\
\hline Helicotylenchus dihystera & $6^{+}$ & & & & & & & \\
\hline H. labiatus & $16^{*}$ & & 1 & $1 *$ & 3 & & $1^{*}$ & \\
\hline H. paraplatyurus* & & 1 & & & & & & \\
\hline H. pseudorobustus & 3 & & & & & & 1 & \\
\hline Helicotylenchus sp. & 9 & 1 & & & & & & \\
\hline Rotylenchus uniformis & $1 \%$ & & & & & & & \\
\hline Scutellonema brachyurus ${ }^{*}$ & $2^{f}$ & & & & $1^{\text {事 }}$ & & & \\
\hline
\end{tabular}

*Nematodes not previously recorded in New Zealand.

${ }^{\dagger}$ Proposed new pest:host relationship.

Extension to known distribution. 
to a $1 \mathrm{ml}$ sample in a Baermann funnel type apparatus (Hooper 1986a). At the time that the nematodes in the samples were live and fresh a $5 \%$ subsample was heat killed and immediately examined under phase contrast with 10 or $40 \times$ objective. Initial identifications were made for later reference. The remaining $95 \%$ of the sample was heated to $60^{\circ} \mathrm{C}$ for $1 \mathrm{~min}$ and added to an equal volume of $6 \%$ formalin ( $37 \%$ formaldehyde). After a period of fixing in formalin of not less than 4 weeks the samples were examined under $50 x$ binocular magnification, and any plant parasitic nematodes of interest were hand picked into cold lactophenol. The original "fresh" observations were used either to direct selection to include nematodes that could not be confidently identified under initial water mounts or to ignore those that had been identified already. The lactophenol was then heated to a temperature sufficient to cause it to give off visible vapour. Once cool, the nematodes were transferred to permanent mounts of glycerol and examined under high power interference contrast.

Root samples were washed in cold tap water and blotted dry before being finely chopped with clean scissors. No attempt was made to standardise the amount of roots used. Nematodes were extracted by placing the chopped roots into a single-ply paper tissue supported by a plastic mesh in an open ended funnel suspended over a glass boiling tube. These were placed in a Seinhorst mistifier chamber ( $5 \mathrm{~s}$ on : $4 \mathrm{~min} 55 \mathrm{~s}$ off mist cycle) for $48-72 \mathrm{~h}$ (Hooper 1986b). The funnel was not sealed onto the boiling tube so that excess water overflowed the tube allowing the nematodes to accumulate undisturbed in the bottom of the tube. The lower 5 $\mathrm{ml}$ of this extraction was transferred to a smaller tube where the nematodes could be condensed to a

Table 2 Plant parasitic nematodes associated with feijoa (Feijoa sellowiana) in New Zealand, $1998-99$.

\begin{tabular}{|c|c|c|c|c|c|c|c|c|c|}
\hline \multirow[b]{4}{*}{ Nematode } & \multicolumn{8}{|c|}{ Number of sites surveyed (total $=23$ ) } & \multirow[b]{4}{*}{ Source of association info. } \\
\hline & 5 & 5 & 1 & 1 & 3 & 1 & 3 & 4 & \\
\hline & \multicolumn{8}{|c|}{ Crosby et al. (1976) district } & \\
\hline & $\mathrm{AK}$ & WO & $\mathrm{CL}$ & $\mathrm{BP}$ & TK & WI & NN & MB & \\
\hline \multicolumn{10}{|l|}{ Triplonchida } \\
\hline Paratrichodorus minor & 1 & 1 & & & 3 & & 1 & & \\
\hline P. porosus & & & & & 1 & & & & \\
\hline \multicolumn{10}{|l|}{ Dorylaimida } \\
\hline Xiphinema diversicaudatum & & & & & $1^{\ddagger}$ & & & & \\
\hline$X$. americanum & & 1 & & & 1 & & & & \\
\hline \multicolumn{10}{|l|}{ Tylenchida } \\
\hline Meloidogyne hapla & 1 & & & & 1 & & & $1^{\ddagger}$ & \\
\hline Pratylenchus crenatus & 1 & & & & & & & & \\
\hline Pratylenchus penetrans & & & & & $1 \stackrel{+}{*}$ & & & 1 & \\
\hline Paratylenchus projectus & 1 & & & & & & & & \\
\hline Gracilacus straeleni & & & & & & & 1 丰 & & \\
\hline Criconema californicum & $1 \frac{+}{\ddagger}$ & & & & $1^{\dagger}$ & $1^{\text {末 }}$ & & & \\
\hline Mesocriconema sp. & & & & & & & 1 & & \\
\hline Ogma palmatum & & & & & & & $1^{*}$ & & \\
\hline Hemicycliophora sp. & 1 & & & & & & & & \\
\hline Helicotylenchus dihystera & $1 \ddagger$ & & & & & & & & \\
\hline H. labiatus & & & 1 & & 1 & 1 & 1 & & Yeates \& Wouts (1992) \\
\hline H. pseudorobustus & 2 & & & & & & & & \\
\hline H. varicaudatus & & & & & & & 1 & & \\
\hline Helicotylenchus sp. & & 1 & & & & & & & \\
\hline Rotylenchus uniformis & & & & & & $1^{\dagger}$ & $1^{\ddagger}$ & & \\
\hline
\end{tabular}

Extension to known distribution. 
Table 3 Plant parasitic nematodes associated with kiwifruit (Actinidia deliciosa) in New Zealand, $1998-99$.

\begin{tabular}{|c|c|c|c|c|c|c|c|c|c|c|c|}
\hline \multirow[b]{4}{*}{ Nematode } & \multicolumn{10}{|c|}{ Number of sites surveyed (total = 117) } & \multirow[b]{4}{*}{ Source of association info. } \\
\hline & 5 & 12 & 7 & 2 & 63 & 1 & 3 & 1 & 1 & 22 & \\
\hline & \multicolumn{10}{|c|}{ Crosby et al. (1976) district } & \\
\hline & ND & AK & WO & $\mathrm{CL}$ & $\mathrm{BP}$ & GB & $\mathrm{HB}$ & WI & $\mathrm{WN}$ & NN & \\
\hline \multicolumn{12}{|l|}{ Triplonchida } \\
\hline Paratrichodorus minor & 1 & & & & 20 & & 1 & & & 3 & \\
\hline$P$. porosus & & & 2 & & 4 & & 1 & & & $1^{\ddagger}$ & \\
\hline P. lobatus & & & & & & & & & & $1^{\ddagger}$ & \\
\hline Paratrichodorus sp. & & & & & & & & & & 2 & Watson et al. (1992) \\
\hline \multicolumn{12}{|l|}{ Dorylaimida } \\
\hline Xiphinema diversicaudatum & & & & & & & & & & 4 & \\
\hline$X$. americanum & & & & & 2 & & & & & & \\
\hline Longidorus elongatus & & & & & 1 & & & & & 2 & \\
\hline Longidorus sp. & & & & & 1 & & & & & & \\
\hline \multicolumn{12}{|l|}{ Tylenchida } \\
\hline Meloidogyne hapla & 5 & 9 & 4 & 2 & 55 & 1 & 2 & 1 & 1 & 16 & Dale (1971a) \\
\hline Meloidogyne sp. & & & & & 1 & & & & & 1 & \\
\hline Heterodera sp. & & & & & 1 & & & & & & Watson et al. (1992) \\
\hline Pratylenchus crenatus & 1 & & & & 2 & & & & & 2 & \\
\hline$P$. penetrans & & & & & 4 & & & & & 1 & \\
\hline Pratylenchus sp. & & 1 & 2 & & 1 & & & & & & Watson et al. (1992) \\
\hline Paratylenchus elachistus* & & & $1^{\text {事 }}$ & & $7^{\frac{1}{5}}$ & & & & & $4^{\ddagger}$ & \\
\hline$P$. nanus & & & & 1 & & & & & 3 & & \\
\hline Paratylenchus sp. & & & & & 4 & & & & & 1 & Watson et al. (1992) \\
\hline Criconema annuliferum ${ }^{*}$ & & & & & & & & & & $1+$ & \\
\hline Helicotylenchus dihystera & & & & & $1^{\text {㐁 }}$ & & & & & & \\
\hline H. labiatus & 1 & & & & 9 & & & & & 2 & Yeates \& Wouts (1992) \\
\hline H. paraplatyurus & & & 1 & & $2^{\ddagger}$ & & & & & $1+$ & \\
\hline H. pseudorobustus & 1 & 1 & & & 3 & & & & & & \\
\hline Rotylenchus uniformis & & 1 & & & & & & & & 1 & \\
\hline Scutellonema brachyurus & & & & & 2 & & & & & & \\
\hline
\end{tabular}

*Nematodes not previously recorded in New Zealand.

Extension to known distribution. 
$1 \mathrm{ml}$ volume. From this point a procedure similar to that described for the soil samples was followed.

All nematodes species that yielded material suitable for identification were identified to species level. Where a new record (new pest:host relationship, new distribution, new to New Zealand) was suspected, the material was sent to a recognised expert for validation of the identification. All such material was placed in the NPPRL Nematode Collection as physical evidence of the new record, and the information was entered into the New Zealand Ministry of Agriculture and Forestry PPIN (Plant Pest Information Network) database. Where a nematode species was found in the presence of a subtropical subject but a pest:host relationship was not proven, a record was also made in PPIN, in compliance with the greater survey procedure. Validation of the nematode identification was not sought in these cases.

\section{RESULTS AND DISCUSSION}

The results of 319 investigations are shown in Tables 1-6. Where a nematode has previously been recorded in association with the specified host, reference to the original information source is provided. This does not necessarily indicate a pest:host relationship is proven. The original reference should be consulted to ensure the nematode:plant association is sufficiently established for the purposes of the reader. Other nematodes listed in these tables are considered to be new associations. If there is sufficient evidence (e.g., a combination of the following factors: high numbers of nematodes in the sample including gravid females and/or numerous juveniles; extraction from the roots; frequent occurrence with the host in weed free sites) new pest:host relationships are proposed. These are indicated in the Tables, as are extensions to

Table 4 Plant parasitic nematodes associated with passionfruit (Passiflora edulis) in New Zealand, 1998-99.

\begin{tabular}{|c|c|c|c|c|c|c|c|c|}
\hline \multirow[b]{4}{*}{ Nematode } & \multicolumn{7}{|c|}{ Number of sites surveyed (total $=28$ ) } & \multirow[b]{4}{*}{ Source of association info } \\
\hline & 3 & 9 & 1 & 4 & 8 & 2 & 1 & \\
\hline & \multicolumn{7}{|c|}{ Crosby et al. (1976) district } & \\
\hline & ND & $\mathrm{AK}$ & WO & $\mathrm{BP}$ & TK & WN & NN & \\
\hline Triplonchida & & & & & & & & \\
\hline $\begin{array}{l}\text { Paratrichodorus minor } \\
P . \text { porosus }\end{array}$ & $\begin{array}{l}2 \\
2\end{array}$ & & 1 & 3 & 2 & & & Dale et al. (1972) \\
\hline Dorylaimida & & & & & & & & \\
\hline Xiphinema diversicaudatum & 1 & & & 1 & & & & \\
\hline Tylenchida & & & & & & & & \\
\hline Meloidogyne hapla & & 1 & & & 2 & 1 & & \\
\hline M. trifoliophila & 1 & & & & & & & \\
\hline Meloidogyne sp. & 1 & & & 1 & & & & \\
\hline Pratylenchus crenatus ${ }^{\dagger}$ & & 1 & 1 & 1 & $2^{\ddagger}$ & & & \\
\hline$P$. penetrans $^{\dagger}$ & $1^{\ddagger}$ & 1 & & $2^{\ddagger}$ & 4 & & & \\
\hline Pratylenchus sp. & & 1 & & & 2 & & & \\
\hline Zygotylenchus guevarai ${ }^{* \dagger}$ & & & & & $1^{\ddagger}$ & & & \\
\hline Paratylenchus elachistus & & & 1 & 1 & & & & \\
\hline Ogma palmatum & & & & & $1^{*}$ & & & \\
\hline Crossonema civellae & & & & & $1^{\ddagger}$ & & & \\
\hline Tylenchulus semipenetrans & 1 & & & & & & & \\
\hline Helicotylenchus dihystera & 1 & & & 1 & $1^{\ddagger}$ & & & \\
\hline H. labiatus & 1 & 1 & & 1 & 2 & & & \\
\hline H. paraplatyurus & & & $1^{\ddagger}$ & & & & & \\
\hline H. vulgaris & & $1^{\dagger}$ & & & & & & \\
\hline Helicotylenchus sp. & & 2 & & & & & & \\
\hline Rotylenchus uniformis & & & & $1^{\ddagger}$ & $2^{\ddagger}$ & & & \\
\hline
\end{tabular}

*Nematodes not previously recorded in New Zealand.

${ }^{\dagger}$ Proposed new pest : host relationship.

Extension to known distribution. 
distributions and nematodes not previously known to occur in New Zealand.

Six nematodes not previously recorded in New Zealand were identified in this survey. They are: Criconema annuliferum (de Man, 1921) Micoletzky, 1925; Crossonema civellae (Steiner, 1949) Mehta \& Raski, 1971; Paratylenchus elachistus Steiner, 1949; Helicotylenchus paraplatyurus Siddiqi, 1972; Scutellonema brachyurus (Steiner, 1949) Andrassy, 1958; and Zygotylenchus guevarai (Tobar Jimenez, 1963) Braun \& Loof, 1966.

Two adult, female $C$. annuliferum (identification: Knight; validated: W. Wouts) were found in soil from one commercial kiwifruit crop in Appleby (NN) (Knight 2000).

A single specimen of $C$. civellae (identification: Knight; validated: W. Wouts) was extracted from soil from a commercial passionfruit crop on the outskirts of New Plymouth city (TK). No pest:host relationship is proposed for these Criconematids for the same reasons given for P. elachistus below.

Paratylenchus elachistus (identification: Knight; validated: E. Van den Berg) is here offered as the first record in New Zealand, although an earlier observation had been made in Auckland. The specific identity of the earlier find was only confirmed concurrently with this survey. The distribution of $P$. elachistus includes the Crosby et al. (1976) districts ND, AK, CL, WO, BP, NN, and was found associated with avocado, kiwifruit, and passionfruit. P. elachistus are ectoparasites that rarely produce significant disease in their plant hosts, consequently there is little information on their pest:host relationships. No attempt is made here to create such a record, since in all cases the nematodes were extracted from the soil, numbers were only moderate to low; and the possibility of feeding from the roots of other species in the area could not be excluded.

The spiral nematode, $H$. paraplatyurus (identification: Knight; validated: W. Wouts), has not previously been reported in New Zealand. It was found in 10 sites in this survey in six Crosby et al. (1976) districts (ND, AK, WO, BP, WN, NN), where it was associated with five of the six crops surveyed (avocado, kiwifruit, persimmon,

Table 5 Plant parasitic nematodes associated with persimmon (Diospyros kaki) in New Zealand, 1998-99.

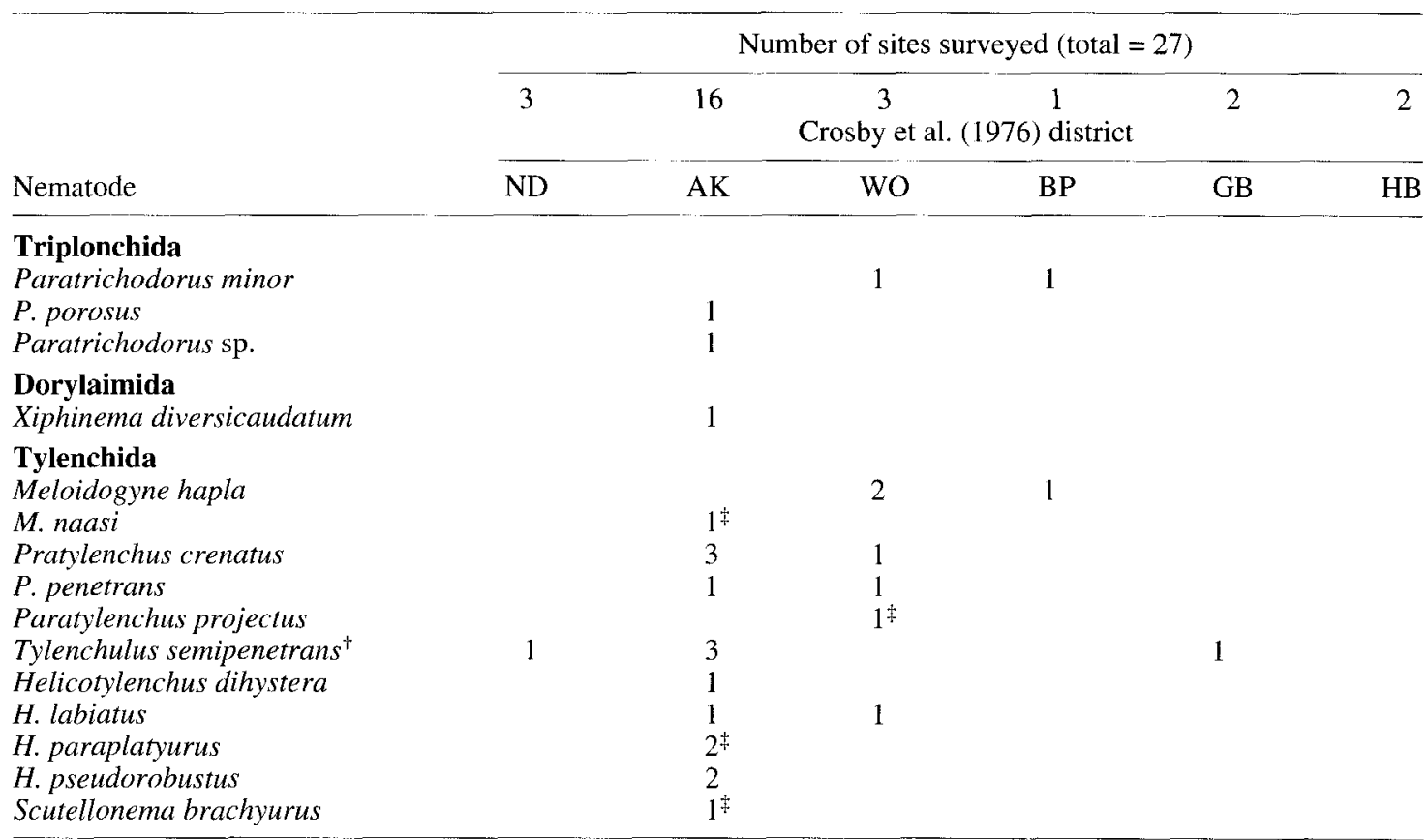

Proposed new pest host relationship.

Extension to known distribution. 
passionfruit, and tamarillo). No pest:host relationship is proposed between this nematode and any of the crops surveyed. It is not charateristic of Helicotylenchus spp. to enter the roots to feed (Siddiqi 2000), therefore they cannot be extracted from root tissues, making it difficult to draw accurate conclusions about their feeding relationships with hosts. However, in at least half of the observations, the site of sampling was considered to be weed free.

Scutellonema brachyurus (S. brachyurum) (identification: Knight; validated: W. Wouts) is here offered as the first record of this nematode in New Zealand. Earlier observations of an unidentified species of Scutellonema, in cultivated orchard soils (Egunjobi 1968), may have been $S$. brachyurus. In this survey, S. brachyurus was found in the soil samples from avocado (ND and BP), kiwifruit (BP), and persimmon (AK). S. brachyurus is a known parasite of woody hosts (Siddiqi 1974) but has not previously been recorded in association with these crops. The low frequency of observations, presence in soil only, and the low numbers observed do not support the proposition that a pest:host relationship is proven with any of these crops.

Zygotylenchus guevarai (identification: Knight; validated: W. Wouts) was extracted in low numbers from the roots of passionfruit in New Plymouth (TK) (Knight 2000). It was not found in the soil samples of this orchard, including soil taken from under the infested vine. $Z$. guevarai is known to have a fairly broad host range (Siddiqi 1975), and although it has not previously been reported as parasitising passionfruit, it is likely that a feeding relationship does exist as the nematodes were found within the roots, but could not be detected in the soil. A new pest:host relationship is proposed for $Z$. guevarai and passionfruit.

Table 6 Plant parasitic nematodes associated with tamarillo (Cyphomandra betacea) in New Zealand, $1998-99$.

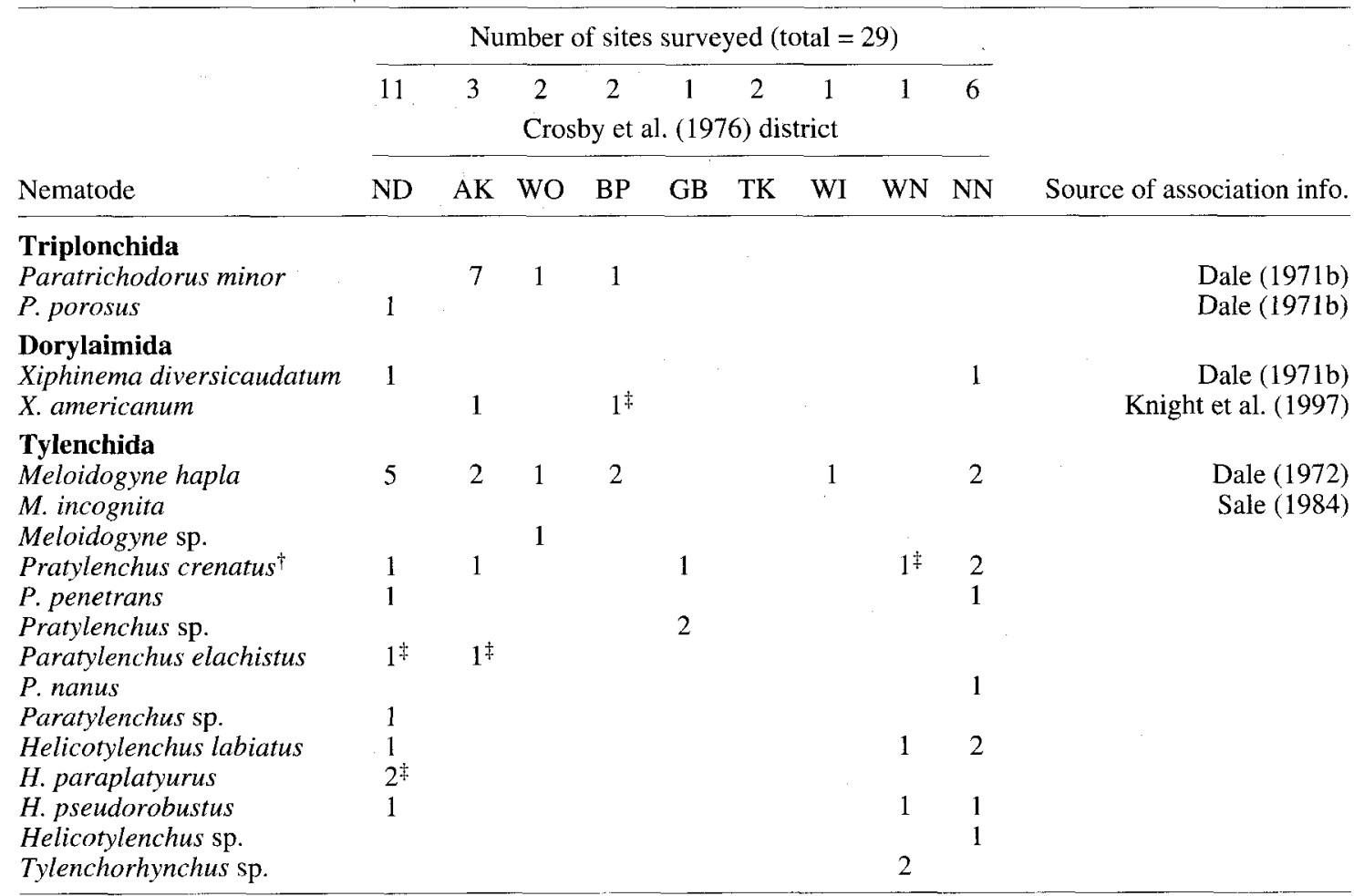

${ }^{\dagger}$ Proposed pest:host relationship.

$\stackrel{+}{\mp}$ Extension to known distribution. 
Five additional new probable pest:host relationships for New Zealand are proposed as a result of this survey.

The citrus nematode, Tylenchulus semipenetrans Cobb, 1913, was recovered from the soil in five out of 27 persimmon sites. High numbers in the roots of persimmon in one weed-free Kerikeri (ND) site is offered as proof of parasitism. Persimmons are a known host of T. semipenetrans in the United States (Nesbitt 1956).

The root lesion nematodes, Pratylenchus crenatus Loof, 1960 and P. penetrans (Cobb, 1917) Filipjev $\&$ Schuurmans Stekhoven, 1941, were found in five and eight of the 28 passionfruit sites examined, respectively. In the case of each nematode, large numbers were extracted from the root tissue and soil, where good weed control had been practised by the grower.

Pratylenchus crenatus was present in six out of 29 tamarillo sites, including 150 nematodes, mostly juveniles, extracted from the root tissues of one Whangarei (ND) sample.

Ten out of 95 avocado sites yielded $M$. hapla. Five of these sites were considered to be weed free. In one of the weed-free sites $M$. hapla females and egg masses were visible on the roots. In two other weed-free sites juveniles were extracted from the roots using mist extraction. The identity of $M$. hapla in avocado samples from this survey have been verified using PCR techniques (Marshall et al. 2001). It is probable that a pest:host relationship exists between $M$. hapla and avocado, although it does not seem to be a strong parasitic relationship, based on the low numbers observed at each site and the low frequency of positive sites.

In each of the new pest:host relationships proposed from observations in this survey, all were nematode species that form close physical associations with the host roots. In each case the nematodes were either fully contained within or partially embedded in the roots. In the cases of hoplolaimids (Helicotylenchus, Scutellonema, Rotylenchus), criconematids (Criconema, Crossonema, Paratylenchus, Gracilacus), longidorids (Xiphinema, Longidorus), and triplonchids (Paratrichodorus), which generally feed ectoparasitically, the observations even of repeated associations, in high numbers, cannot prove a pest:host relationship exists without further ecological study.

\section{ACKNOWLEDGMENTS}

I thank Drs E. Van den Berg and W. Wouts for their validations of these species identifications, and especially Dr Wouts for his help and reference material.

\section{REFERENCES}

Cooper, K. M.; Grandison, G. S. 1987: Effects of Vesicular-Arbuscular Mycorrhizal fungi on infection of tamarillo (Cyphomandra betacea) by Meliodogyne incognita in fumigated soil. Plant Disease 71 : 1101-1106.

Crosby, T. K.; Dugdale, J. S.; Watt, J. C. 1976: Recording specimen localities in New Zealand: an arbitrary system of areas and codes defined. New Zealand Journal of Zoology 3: 69.

Dale, P. S. 1971a: Root knot nematodes. New Zealand Journal of Agriculture 122: 33-37.

Dale, P. S. 1971b: New records of nematode vectors of plant viruses. New Zealand Entomologist 5: 94-95.

Dale, P. S. 1972: List of plant hosts of nematodes in New Zealand. New Zealand Journal of Science 15: 442-448.

Dale, P. S.; Dance, H. M.; Boesewinkel, H. J.; Nicholson, A. 1972: Research in the New Zealand Department of Agriculture 1970-71. Wellington, New Zealand Department of Agriculture.

Egunjobi, O. A. 1968: An ecological study of some soil nematodes associated with apple trees in New Zealand grassed orchard. New Zealand Journal of Agricultural Research 11: 386-406.

Hooper, D. J. 1986a: Extraction of free-living stages from soil. In: Southey, J. F. ed. Laboratory methods for work with plant and soil nematodes. Reference Book 402, ADAS Ministry of Agriculture, Fisheries and Food. Pp. 5-30.

Hooper, D. J. 1986b: Extraction of nematodes from plant material. In: Southey, J. F. ed. Laboratory methods for work with plant and soil nematodes Reference Book 402, ADAS Ministry of Agriculture, Fisheries and Food. Pp. 51-58.

Knight, K. 2000: Some plant-parasitic nematodes recently recorded in New Zealand. Species 2000: New Zealand. Proceedings of the Millennial Symposium: review and inventory of New Zealand's biodiversity, Wellington, 1-5 February 2000. 
Knight, K. W. L.; Barber, C. J.; Page, G. D. 1997: Plantparasitic nematodes of New Zealand recorded by host association. Supplement to the Journal of Nematology 29(4S): 640-656.

Marshall, J. W.; Zijlstra, C.; Knight, K. W. L. 2001: First record of Meloidogyne fallax (Karssen, 1996) in New Zealand. Australasian Plant Pathology 30: 283-284.

Nesbitt, R. B. 1956: New host plants of plant parasitic nematodes in California. Plant Disease Reporter 40: 276 .

Sale, P. R. 1984: Tamarillos pests and diseases. AgLink HPP298. Wellington, New Zealand, Ministry of Agriculture and Fisheries.

Sale, P. R. 1985: Kiwifruit culture. Government Printer, Wellington, New Zealand. P. 61.

Siddiqi, M. R. 1974: Scutellonema brachyurum. C.I.H. Descriptions of Plant-parasitic nematodes Set 4, No. 54.
Siddiqi, M. R. 1975: Zygotylenchus guevarai, C.I.H. Descriptions of Plant-parasitic nematodes Set 5, No. 65.

Siddiqi, M. R. 2000: Tylenchida parasites of plants and insects. Second edition. CABI Publishing. P. 4.

Watson, R. N.; Wilson, E. A.; Marsden, R. S. 1992: Distribution of plant-parasitic nematodes in the rhizosphere of kiwifruit. Acta Horticulturae 2: 537-543.

Whitehead, A. G.; Hemming, J. R. 1965: A comparison of some quantitative methods of extracting some small vermiform nematodes from soil. Annals of Applied Biology 55: 25-38.

Yeates, G. W.; Wouts, W. M. 1992: Helicotylenchus spp. (Nematoda: Tylenchida) from managed soils in New Zealand. New Zealand Journal of Zoology 19: 13-23. 